\title{
Sorbicillinoid Derivatives From Sponge-Derived Fungus Trichoderma reesei (HN-2016-018)
}

\section{OPEN ACCESS}

Edited by: Jinwei Zhang,

University of Exeter, United Kingdom

Reviewed by:

Tibor Kurtán,

University of Debrecen, Hungary Weaam Ebrahim, Heinrich Heine University Düsseldorf,

Germany

*Correspondence:

Chang-Yun Wang

changyun@ouc.edu.cn

tThese authors have contributed equally to this work

Specialty section: This article was submitted to

Microbiotechnology, a section of the journal

Frontiers in Microbiology

Received: 19 March 2020

Accepted: 25 May 2020

Published: 23 June 2020

Citation:

Rehman SU, Yang L-J, Zhang Y-H, Wu J-S, Shi T, Haider W

Shao C-L and Wang C-Y (2020)

Sorbicillinoid Derivatives From Sponge-Derived Fungus Trichoderma reesei (HN-2016-018).

Front. Microbiol. 11:1334 doi: 10.3389/fmicb.2020.01334
Saif Ur Rehman 1,2,3,4t, Lu-Jia Yang 1,2,3t, Ya-Hui Zhang1,2,3, Jing-Shuai Wu ${ }^{1,2,3}$, Ting Shi,2,3, Waqas Haider ${ }^{1,2,3}$, Chang-Lun Shao ${ }^{1,2,3}$ and Chang-Yun Wang ${ }^{1,2,3 *}$

${ }^{1}$ Key Laboratory of Marine Drugs, The Ministry of Education of China, School of Medicine and Pharmacy, Ocean University of China, Qingdao, China, ${ }^{2}$ Institute of Evolution \& Marine Biodiversity, Ocean University of China, Qingdao, China, ${ }^{3}$ Laboratory for Marine Drugs and Bioproducts, Qingdao National Laboratory for Marine Science and Technology, Qingdao, China, ${ }^{4}$ Department of Pharmacy, Faculty of Medical and Health Sciences, University of Poonch Rawalakot, Rawalakot, Pakistan

Six new sorbicillinoids, trichoreeseione A (1) and B (2), trichodermolide B (3), 13hydroxy-trichodermolide (4), 24-hydroxy-trichodimerol (5), 15-hydroxy-bisvertinol (7), together with three known analogs, trichodimerol (6), 24-hydroxy-bisvertinol (8), and bisvertinol (9), were isolated from the sponge-derived fungus Trichoderma reesei (HN-2016-018). Their structures including absolute configurations were elucidated by analysis of NMR, MS data, and calculated ECD spectra. Compounds $\mathbf{1}$ and $\mathbf{2}$ with a characteristic naphthalene-trione ring were firstly reported in sorbicillinoid family. Compounds $\mathbf{3}$ and $\mathbf{4}$ were two rare sorbicillinoids containing a unique bicycle [3.2.1] lactone skeleton, while $\mathbf{3}$ with a propan-2-one moiety was also recorded first time in this family. Compound $\mathbf{5}$ displayed cytotoxic activity against A549, MCF-7, and HCT116 cell lines with the $\mathrm{IC}_{50}$ values of $5.1,9.5$, and $13.7 \mu \mathrm{M}$, respectively.

Keywords: sponge-derived fungus, Trichoderma reesei, sorbicillinoid, naphthalene-trione, cytotoxic activity

\section{INTRODUCTION}

Sorbicillionids are a family of hexaketide metabolites with a characteristic sorbyl side chain residue (Harned and Volp, 2011), which was firstly isolated as an impurity in penicillin in 1948 (Andrade et al., 1992). Since then more than 100 analogs of sorbicillinoids have been isolated, which could be classified into monomeric, dimeric, trimeric, and polycyclic sorbicillinoids, and vertinolides according to their basic structural features (Harned and Volp, 2011). Sorbicillinoid family possesses extensive pharmacological effects including cytotoxic (Du et al., 2009; Ei-Elimat et al., 2015), antimicrobial (Ei-Elimat et al., 2015), antiviral (Peng et al., 2014), anti-inflammatory (Zhang et al., 2019), radical scavenging (Abe et al., 1998), and anti-diabetic activities (Cao et al., 2019). Majority of sorbicillionids were reported from 10 genera of fungi: Penicillium, Phaeoacremonium, Trichoderma, Aspergillus, Phialocephala, Scytalidium, Clonostachys, Acremonium, Paecilomyces, and Verticillium (Meng et al., 2016). In recent years, marine-derived fungi have emerged as an important resource for sorbicillinoids. Diverse sorbicillinoid analogs with unique skeletons have been reported from sponge associated fungi. For example, a group of sorbicillionids, saturnispols A-H possessing excellent antibacterial activity, especially against gram negative bacteria, were isolated from spongederived fungus Trichoderma saturnisporum DI-IA (Meng et al., 2018), while a series of dimeric and 
monomeric sorbicillinoid derivatives with potent antiinflammatory activity were reported from sponge-associated fungus Trichoderma reesei 4670 (Zhang et al., 2019).

During our recent research for exploration of new structurally diverse bioactive natural products from marine invertebrates and their symbiotic microorganisms (Liu et al., 2019), a variety of new secondary metabolites with multiple biological activities have been obtained from sponge-derived fungi (Li et al., 2012; Qi et al., 2013; Zhao et al., 2015; Wang et al., 2018). In this study, the strain T. reesei (HN-2016-018) isolated from an unidentified sponge collected from the South China Sea attracted our attention because the EtOAc extract from its fermentation broth exhibited cytotoxic activity. Chemical investigation led to the isolation of nine sorbicillionoid derivatives (Figure 1), including six new sorbicillionoids, trichoreeseione A (1), trichoreeseione B (2), trichodermolide B (3), 13-hydroxy-trichodermolide (4), 24-hydroxy-trichodimerol (5), and 24-hydroxy-bisvertinol (7), along with three known analogs, trichodimerol (6) (Andrade et al., 1992), 15 hydroxy-bisvertinol (8) (Zhang et al., 2019), and bisvertinol (9) (Trifonov et al., 1986). Herein, we report the isolation, structural elucidation, and cytotoxic activities of these compounds.

\section{MATERIALS AND METHODS}

\section{General Experimental Procedure}

The optical rotations were measured on a JASCO P-1020 digital polarimeter. IR spectra were recorded on a Nicolet-Nexus- 470 spectrometer using $\mathrm{KBr}$ pellets (Thermo Electron, Waltham, MA, United States). UV spectra were recorded using a Milton Roy UV-Vis spectrophotometer. NMR spectra were acquired using a JEOL JEMECP NMR spectrometer (JEOL, Tokyo, Japan) (600 MHz for ${ }^{1} \mathrm{H}, 150 \mathrm{MHz}$ for ${ }^{13} \mathrm{C}$ ) and BRUKER AVANCE NEO NMR spectrometer (BRUKER, United States) (400 MHz for ${ }^{1} \mathrm{H}$, and $100 \mathrm{MHz}$ for ${ }^{13} \mathrm{C}$ ), using TMS as an internal standard. ECD spectra were recorded on a JASCO J-815 circular dichroism spectrometer (JASCO Electric Co., Ltd., Tokyo, Japan). ESIMS spectra were measured on a Micromass Q-TOF spectrometer (Waters Corp., Manchester, United Kingdom). HPLC separation was performed using a Hitachi L-2000 HPLC system (Hitachi High Technologies, Tokyo, Japan) coupled with a Hitachi L-2455 photodiode array detector. A Kromasil $\mathrm{C}_{18}$ semi-preparative HPLC column $(250 \times 10 \mathrm{~mm}, 5 \mu \mathrm{m})$ (Eka Nobel, Bohus, Sweden) was used. Silica gel (Qingdao Marine Chemical Group Co., Qingdao, China) and Sephadex LH-20 (Amersham Biosciences Inc., Piscataway, NJ, United States) were used for column chromatography. Precoated silica gel GF254 plates (Yantai Zifu Chemical Group Co., Yantai, China) were used for analytical TLC.

\section{Fungal Material}

The fungal strain T. reesei (HN-2016-018) was separated from the internal fresh tissue of an unidentified sponge collected from the South China Sea in October 2016. The fungal strain was recognized on the basis of its morphological traits and by amplification and sequencing of the DNA sequences of the ITS region. The fungus was identified as T. reesei whose 500 base pair ITS sequence had $99 \%$ sequence identity to that of $T$. reesei. The phylogenetic tree (Supplementary Figure S50) was constructed using the neighbor joining method (Saitou and Nei, 1987). The distance calculations, tree construction, and bootstrap analysis were performed with the software MEGA 7 (Felsenstein, 1985). The strain was deposited in the Key Laboratory of Marine Drugs, the Ministry of Education of China, School of Medicine and Pharmacy, Ocean University of China, Qingdao, China, with the Gene Bank (NCBI) accession number MT367415.

\section{Fermentation, Extraction, and Isolation}

The fungal strain T. reesei (HN-2016-018) was cultivated in $80 \mathrm{~L}$ PDB medium at r.t. for 1 month. Broth and mycelia in fermented culture were separated by filtration. The filtrate was extracted three times with equal volume of EtOAc, and the mycelia were soaked in EtOAc $(3 \times 5000 \mathrm{~mL})$. The TLC profiles of these two parts were similar, so these extracts were combined and obtained the EtOAc extract (103 g). The extract was subjected to VLC on silica gel (100-200 mesh) eluting with a combination solvent of PE/EtOAc in increasing polarity (90:10, 50:50, 30:70, 0:100) followed by $\mathrm{CH}_{2} \mathrm{Cl}_{2} / \mathrm{MeOH}$ (from 90:10 to $30: 70$ ) to obtain six fractions (Fr.1-Fr.6). Fr.3 was subjected to silica gel column chromatography (CC) to obtain two sub-fractions (Fr.31 and Fr.3-2). Fr.3-1 was chromatographed over a Sephadex LH-20 column using $\mathrm{MeOH}$ as mobile phase and afterward isolated by semi-preparative HPLC $\left(75 \% \mathrm{MeOH} / \mathrm{H}_{2} \mathrm{O}\right)$ to yield 1 (7.0 mg) and 2 (5.5 mg). Fr.3-2 was separated by HPLC (70\% $\left.\mathrm{CH}_{3} \mathrm{CN} / \mathrm{H}_{2} \mathrm{O}\right)$ to give $4(7 \mathrm{mg})$. Fr. 4 was fractionated with Sephadex LH-20 column using $\mathrm{PE}-\mathrm{CH}_{2} \mathrm{Cl}_{2}-\mathrm{MeOH}$ (v/v, 2:1:1) as mobile phase to achieve four sub-fractions (Fr.4-1 to Fr.4-4). Pure compound 9 (10 mg) was obtained from Fr.4-1 by CC on Sephadex LH-20 with mobile phase $\mathrm{CH}_{2} \mathrm{Cl}_{2}-\mathrm{MeOH}$ (v/v, 1:1). Fr.4-2 was eluted with PE-EtOAc (v/v, 70:30) on silica gel CC and then purified with RP-HPLC $\left(70 \% \mathrm{MeOH} / \mathrm{H}_{2} \mathrm{O}\right)$ to afford 3 (6 mg). Fr.4-3 was processed with Sephadex LH-20 column and then further fractioned by RP-HPLC $\left(65 \% \mathrm{MeOH} / \mathrm{H}_{2} \mathrm{O}\right)$ to give 5 (8 mg) and 6 (25 mg). Fr.4-4 was subjected to RP-HPLC (45\% $\left.\mathrm{MeOH} / \mathrm{H}_{2} \mathrm{O}\right)$ to afford 7 (4.5 $\left.\mathrm{mg}\right)$ and $8(12 \mathrm{mg})$.

Trichoreeseione A (1) yellow oil; $[\alpha] 25 \mathrm{D}-42.7$ (c 0.1, $\mathrm{MeOH}) ; \mathrm{UV}(\mathrm{MeOH}) \lambda_{\max }(\log \varepsilon) 324(4.784) \mathrm{nm}$; ECD (c $2.8 \mathrm{mM}, \mathrm{MeOH}) \lambda \max (\Delta \varepsilon) 227(-8.9), 252(+25.1), 288$ $(-20.8) \mathrm{nm}$; IR $(\mathrm{KBr}) v_{\max } 3614,3566,3525,1700,1683,1509$, 1398, $1026 \mathrm{~cm}^{-1} ;{ }^{1} \mathrm{H}$ and ${ }^{13} \mathrm{C}$ NMR see Table 1; HR-ESIMS $\mathrm{m} / z$ $357.1692[\mathrm{M}+\mathrm{H}]^{+}$(calcd for $\mathrm{C}_{21} \mathrm{H}_{25} \mathrm{O}_{5}, 357.1697$ ), 379.1511 $[\mathrm{M}+\mathrm{Na}]^{+}$(calcd for $\left.\mathrm{C}_{21} \mathrm{H}_{24} \mathrm{O}_{5} \mathrm{Na}, 379.1516\right)$.

Trichoreeseione B (2) yellow oil; $[\alpha] 25 \mathrm{D}-39.9$ (c 0.1, $\mathrm{MeOH}) ; \mathrm{UV}(\mathrm{MeOH}) \lambda_{\max }(\log \varepsilon) 307$ (4.236) nm; ECD (c $2.7 \mathrm{mM}, \mathrm{MeOH}) \lambda \max (\Delta \varepsilon) 226(-6.8), 251(+20.2), 286$ $(-18.2) \mathrm{nm}$; IR $(\mathrm{KBr}) v_{\max } 3629,3567,1700,1683,1650,1521$, $1457 \mathrm{~cm}^{-1} ;{ }^{1} \mathrm{H}$ and ${ }^{13} \mathrm{C}$ NMR see Table 1; HR-ESIMS $\mathrm{m} / z$ $373.1642[\mathrm{M}+\mathrm{H}]^{+}$(calcd for $\left.\mathrm{C}_{21} \mathrm{H}_{25} \mathrm{O}_{6}, 373.1646\right)$.

Trichodermolide B (3) yellow oil; $[\alpha] 25 \mathrm{D}+64.2$ (c 0.1 , $\mathrm{MeOH}) ; \mathrm{UV}(\mathrm{MeOH}) \lambda_{\max }(\log \varepsilon) 308$ (4.65) nm; ECD (c $1.40 \mathrm{mM}, \mathrm{MeOH}) \lambda \max (\Delta \varepsilon) 221(-27.4), 267(+27.1) \mathrm{nm} ; \mathrm{IR}$ $(\mathrm{KBr}) v_{\max } 3023,2934,1785,1721,1683,1634,1597,1436,1381$, 1186, $979 \mathrm{~cm}^{-1} ;{ }^{1} \mathrm{H}$ and ${ }^{13} \mathrm{C}$ NMR see Table 2; HR-ESIMS $\mathrm{m} / z$ 

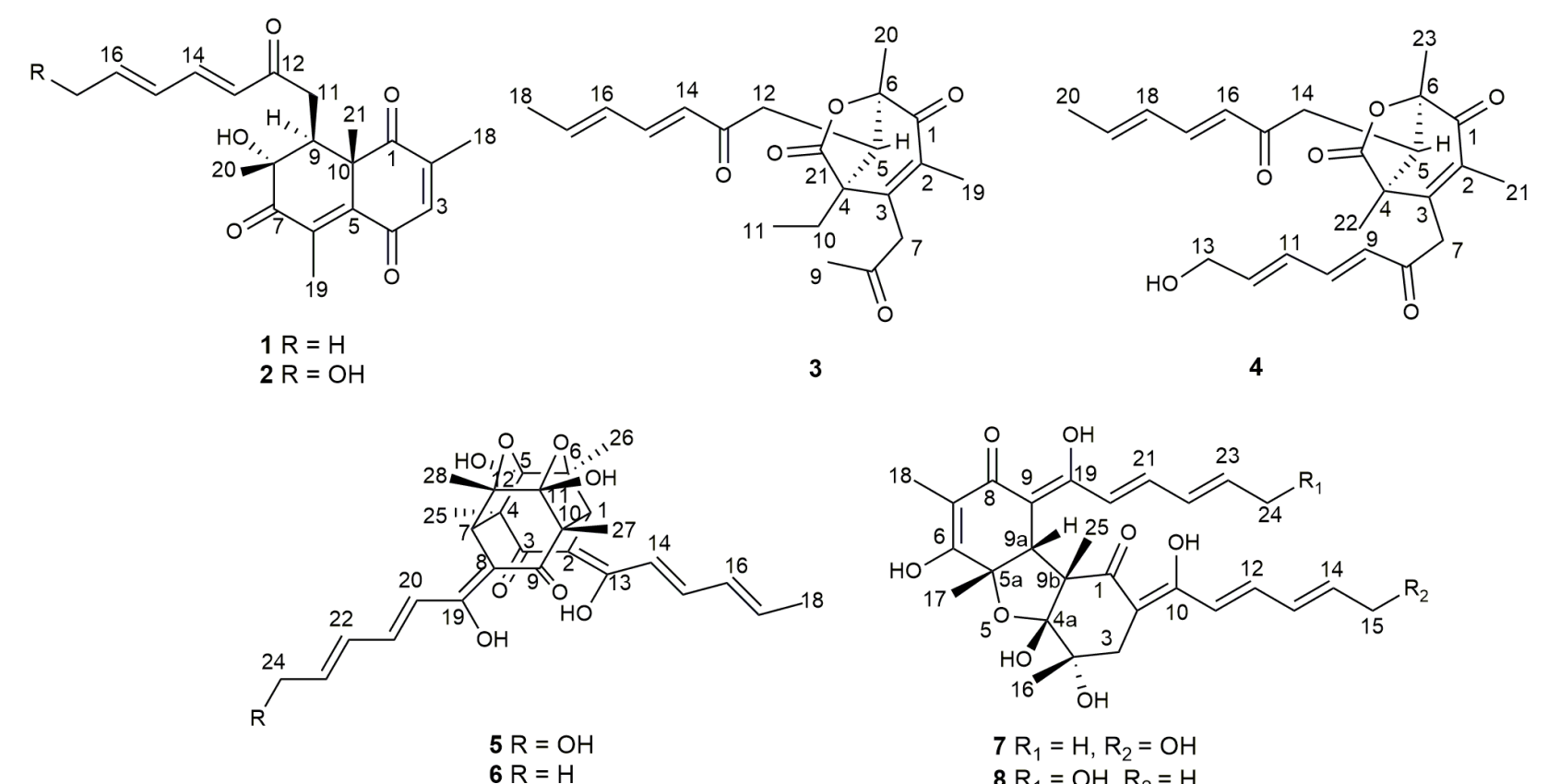

4

$6 \mathrm{R}=\mathrm{H}$

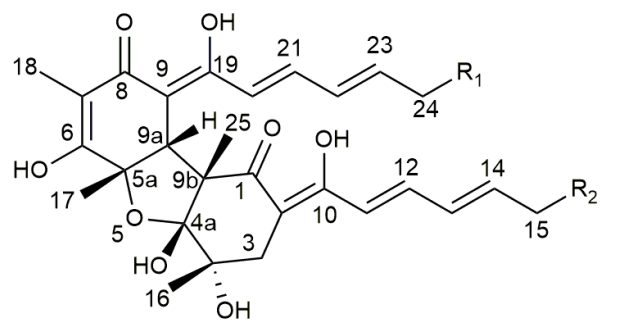

$$
\begin{aligned}
& 7 \mathrm{R}_{1}=\mathrm{H}, \mathrm{R}_{2}=\mathrm{OH} \\
& 8 \mathrm{R}_{1}=\mathrm{OH}, \mathrm{R}_{2}=\mathrm{H} \\
& 9 \mathrm{R}_{1}=\mathrm{H}, \mathrm{R}_{2}=\mathrm{H}
\end{aligned}
$$

FIGURE 1 | Structures of isolated compounds 1-9.

$359.1861[\mathrm{M}+\mathrm{H}]^{+}$(calcd for $\mathrm{C}_{21} \mathrm{H}_{27} \mathrm{O}_{5}, 359.1853$ ), 381.1672 $[\mathrm{M}+\mathrm{Na}]^{+}$(calcd for $\mathrm{C}_{21} \mathrm{H}_{26} \mathrm{O}_{5} \mathrm{Na}, 381.1672$ ).

13-Hydroxy-trichodermolide (4) yellow amorphous powder; $[\alpha] 25 \mathrm{D}+27.6$ (c 0.1, MeOH); UV $(\mathrm{MeOH}) \lambda_{\max }(\log \varepsilon)$ 272 (4.18) nm; IR (KBr) $v_{\max } 3023,2934,1785,1721,1683$, 1634, 1597, 1436, 1381, 1186, $979 \mathrm{~cm}^{-1}$; ECD (c $1.12 \mathrm{mM}$, $\mathrm{MeOH}) \lambda \max (\Delta \varepsilon) 222(-9.9), 266(+7.8) \mathrm{nm} ;{ }^{1} \mathrm{H}$ and ${ }^{13} \mathrm{C}$ NMR see Table 2; HR-ESIMS $m / z 413.1956[\mathrm{M}+\mathrm{H}]^{+}$(calcd for $\left.\mathrm{C}_{24} \mathrm{H}_{29} \mathrm{O}_{6}, 413.1959\right), 435.1773[\mathrm{M}+\mathrm{Na}]^{+}$(calcd for $\mathrm{C}_{24} \mathrm{H}_{28} \mathrm{O}_{6} \mathrm{Na}, 435.1778$ ).

24-Hydroxy-trichodimerol (5) yellow amorphous powder; $[\alpha] 25 \mathrm{D}-405.6$ (c 0.1, MeOH); UV (MeOH) $\lambda_{\max }(\log \varepsilon) 358$ (4.332) nm; ECD (c $1.07 \mathrm{mM}, \mathrm{MeOH}) \lambda \max (\Delta \varepsilon) 338(+56.1)$, $383(-83.5) \mathrm{nm}$; IR (KBr) $v_{\max } 3435,2979,2933,1615,1297$, 1178, $1121 \mathrm{~cm}^{-1} ;{ }^{1} \mathrm{H}$ and ${ }^{13} \mathrm{C}$ NMR see Table 3; HR-ESIMS $\mathrm{m} / z$ 513.2129 $[\mathrm{M}+\mathrm{H}]^{+}$(calcd for $\mathrm{C}_{28} \mathrm{H}_{33} \mathrm{O}_{9}, 513.2130$ ).

15-Hydroxy-bisvertinol (7) yellow powder; $[\alpha] 25 \mathrm{D}-377$ (c $0.1, \mathrm{MeOH}) ; \mathrm{UV}(\mathrm{MeOH}) \lambda_{\max }(\log \varepsilon) 348 \mathrm{~nm}$ (3.874); ECD (c $1.95 \mathrm{mM}, \mathrm{MeOH}) \lambda \max (\Delta \varepsilon) 346(+44.6), 403(-71.4) \mathrm{nm}$; IR $(\mathrm{KBr}) v_{\max } 3739,3390,3265,2933,1711,1612,1556,1361$, $1027 \mathrm{~cm}^{-1}$; ${ }^{1} \mathrm{H}$ and ${ }^{13} \mathrm{C}$ NMR see Table 3; HR-ESIMS $\mathrm{m} / z$ 513.2136 [M - H] $]^{-}$(calcd for $\left.\mathrm{C}_{28} \mathrm{H}_{33} \mathrm{O}_{9}, 513.2130\right)$.

\section{ECD Computational Methods}

The MMFF94S force field was used for conformational searches of $(8 R, 9 S, 10 S)-\mathbf{1},(8 S, 9 R, 10 R)-\mathbf{1}$, and $(4 S, 5 R, 6 S)-\mathbf{3}$, respectively. All conformers [20 for $(8 R, 9 S, 10 S)-\mathbf{1}, 32$ for $(8 S, 9 R, 10 R)-\mathbf{1}$ and 19 for $(4 S, 5 R, 6 R)-3$ ] were optimized at the B3LYP/6-31G(d) level using the Gaussian 09 and then further optimized at the B3LYP/6$311+\mathrm{G}(\mathrm{d})$ level. The ECD spectrum was calculated by the
TDDFT method with the basis set at B3LYP/6-311++G(2d,p) level and simulated by Boltzmann distributions in SpecDis 1.62 (Bruhn et al., 2013).

\section{Biological Assay}

Human tumor cells, including colonic (HCT116 and SW480), lung carcinoma (A-549), hepatocellular carcinoma (HepG2), cervical carcinoma (HeLa), breast cancer (MCF-7), and human normal cells, including human umbilical vein endothelial cells (HUVEC) and hepatocytes CLiver cells were cultured in RPMI 1640 medium supplemented with $10 \%$ heat inactivated FBS (fetal bovine serum), $2 \mathrm{mM} \mathrm{L}$-glutamine and combination of antibiotics penicillin $100 \mathrm{units} / \mathrm{ml}$ and streptomycin $100 \mathrm{~g} / \mathrm{ml}$ were used to avoid contamination in culture medium. All samples were dissolved in DMSO. The adriamycin was used as a positive control and DMSO was used as a negative control (Wu et al., 2020).

The cytotoxicity of the isolated compounds was determined by sulphorhodamine B assay (Skehan et al., 1990). Cells in logarithmic growth stage were inoculated into 96-well tissue culture plates with 5000 cells/well $(180 \mu \mathrm{L} /$ well $)$ for $24 \mathrm{~h}$ before treatment with the tested compounds to allow attachment of the cells to the plate. Cells were exposed to the six different concentrations $(1.25,2.5,5,10,20$, and $40 \mu \mathrm{M})$ in four parallel. After $72 \mathrm{~h}$ of drug action, cold trichloroacetic acid (TCA, 50\% $\mathrm{w} / \mathrm{v}$ ) was added into each well to fix the cell. After several washings, cells were stained by $0.4 \%(\mathrm{w} / \mathrm{v})$ SRB solution for $10 \mathrm{~min}$ in dark place. Excess stain was washed with $1 \%(\mathrm{v} / \mathrm{v})$ glacial acetic acid. After drying overnight, the SRB-stained cells were dissolved with $150 \mu \mathrm{L} /$ pore Tris solution and the color 
TABLE 1 | ${ }^{1} \mathrm{H}(600 \mathrm{MHz})$ and ${ }^{13} \mathrm{C}$ NMR $(150 \mathrm{MHz})$ spectroscopic data for compounds 1-2.

\begin{tabular}{|c|c|c|c|c|}
\hline \multirow[t]{2}{*}{ No. } & \multicolumn{2}{|c|}{1 in $\mathrm{CDCl}_{3}$} & \multicolumn{2}{|c|}{2 in $\mathrm{CDCl}_{3}$} \\
\hline & $\delta_{c}$ type & $\delta_{H},(J$ in $\mathrm{Hz})$ & $\delta_{C}$, type & $\delta_{\mathrm{H}},(\boldsymbol{J}$ in $\mathrm{Hz})$ \\
\hline 1 & 199.1, C & & 199.0, C & \\
\hline 2 & $148.8, \mathrm{C}$ & & $148.7, \mathrm{C}$ & \\
\hline 3 & $137.7, \mathrm{CH}$ & $6.75, \mathrm{~s}$ & $137.7, \mathrm{CH}$ & $6.76, \mathrm{~s}$ \\
\hline 4 & 190.5, C & & 190.3, C & \\
\hline 5 & 147.6, C & & 147.6, C & \\
\hline 6 & 133.6, C & & 133.5, C & \\
\hline 7 & 202.5, C & & 202.3, C & \\
\hline 8 & $74.9, \mathrm{C}$ & & $74.8, \mathrm{C}$ & \\
\hline 9 & $41.9, \mathrm{CH}$ & 3.45, dd $(7.5,3.7)$ & $42.0, \mathrm{CH}$ & 3.44 , dd $(7.7,3.8)$ \\
\hline 10 & $54.4, \mathrm{C}$ & & $54.3, \mathrm{C}$ & \\
\hline \multirow[t]{2}{*}{11} & $38.4, \mathrm{CH}_{2}$ & 2.94, dd $(15.5,7.5)$ & 38.6, $\mathrm{CH}_{2}$ & $2.96, \mathrm{dd}(15.5,7.7)$ \\
\hline & & 2.84, dd $(15.5,3.7)$ & & $2.86, \mathrm{dd}(15.5,3.8)$ \\
\hline 12 & 198.8, C & & 198.5, C & \\
\hline 13 & 127.3, $\mathrm{CH}$ & $6.27, \mathrm{~d}(15.5)$ & 128.6, $\mathrm{CH}$ & $6.38, d(15.5)$ \\
\hline 14 & 143.0, $\mathrm{CH}$ & $7.30, \mathrm{dd}(15.5,9.7)$ & $141.4, \mathrm{CH}$ & $7.34, \mathrm{dd}(15.5,10.9)$ \\
\hline 15 & $130.5, \mathrm{CH}$ & $6.21, \mathrm{~m}$ & $129.4, \mathrm{CH}$ & $6.45, \mathrm{~m}$ \\
\hline 16 & 140.3, $\mathrm{CH}$ & 6.20, m & 141.6, $\mathrm{CH}$ & $6.29, \mathrm{dt}(15.5,4.2)$ \\
\hline 17 & $18.9, \mathrm{CH}_{3}$ & $1.87, \mathrm{~d}(5.1)$ & $62.9, \mathrm{CH}_{2}$ & 4.31, d (4.2) \\
\hline 18 & $17.0, \mathrm{CH}_{3}$ & $2.03, \mathrm{~s}$ & $16.9, \mathrm{CH}_{3}$ & $2.04, \mathrm{~s}$ \\
\hline 19 & $12.9, \mathrm{CH}_{3}$ & $2.01, \mathrm{~s}$ & $12.8, \mathrm{CH}_{3}$ & $2.02, \mathrm{~s}$ \\
\hline 20 & $22.4, \mathrm{CH}_{3}$ & $1.34, \mathrm{~s}$ & $22.4, \mathrm{CH}_{3}$ & $1.34, \mathrm{~s}$ \\
\hline 21 & $21.5, \mathrm{CH}_{3}$ & $1.57, \mathrm{~s}$ & $21.4, \mathrm{CH}_{3}$ & $1.57, \mathrm{~s}$ \\
\hline $8-\mathrm{OH}$ & & 3.55 , brs & & 3.76 , brs \\
\hline
\end{tabular}

intensity was measured in microplate reader at $540 \mathrm{~nm}$. The $\mathrm{IC}_{50}$ values were analyzed using Graph Pad Prism 5 (GraphPad Software, Inc., La Jolla, CA, United States). The biological assay was carried out under proper aseptic environment to prevent contamination from bacteria, fungi, mycoplasma, and cross contaminations with other cell lines.

\section{Statistical Analysis}

The bioassay results were expressed as mean values \pm SD. The $\mathrm{IC}_{50}$ values, i.e., the concentrations necessary for $50 \%$ inhibition, were calculated from the dose response curves using non-linear regression.

\section{RESULTS}

\section{Structure Elucidation}

Trichoreeseione A (1) was isolated as a yellow oil with a molecular formula $\mathrm{C}_{21} \mathrm{H}_{24} \mathrm{O}_{5}$, based on its HR-ESIMS $\mathrm{m} / z$ $357.1692[\mathrm{M}+\mathrm{H}]^{+}\left(\right.$calcd for $\mathrm{C}_{21} \mathrm{H}_{25} \mathrm{O}_{5}, 357.1697[\mathrm{M}+\mathrm{H}]^{+}$), possessing 10 degrees of unsaturation. The ${ }^{1} \mathrm{H}$ NMR spectrum of 1 presented five olefinic protons, one methine, one methylene, five methyls, and one hydroxyl proton $\left(\delta_{H} 3.55\right.$, brs) (Table 1). The ${ }^{13} \mathrm{C}$ NMR spectrum exhibited the presence of 21 carbon signals, including eight olefinic carbons, four carbonyl groups and nine $\mathrm{sp}^{3}$ hybridized carbons (Table 1), which indicated
TABLE $2 \mid{ }^{1} \mathrm{H}(600 \mathrm{MHz})$ and ${ }^{13} \mathrm{C}$ NMR (150 MHz) for compounds 3-4.

\begin{tabular}{|c|c|c|c|c|}
\hline \multirow[t]{2}{*}{ No. } & \multicolumn{2}{|c|}{3 in DMSO-d 6} & \multicolumn{2}{|c|}{4 in $\mathrm{CDCl}_{3}$} \\
\hline & $\delta_{\mathrm{C}}$, type & $\delta_{H}(J$ in $\mathrm{Hz})$ & $\delta_{\mathrm{C}}$, type & $\delta_{H}(J$ in $\mathrm{Hz})$ \\
\hline 1 & 191.2, C & & 191.2, C & \\
\hline 2 & $133.9, \mathrm{C}$ & & $134.3, \mathrm{C}$ & \\
\hline 3 & $150.9, \mathrm{C}$ & & 149.3, C & \\
\hline 4 & $55.9, \mathrm{C}$ & & $51.7, \mathrm{C}$ & \\
\hline 5 & $50.0, \mathrm{CH}$ & 3.37, m & $55.9, \mathrm{CH}$ & 3.33, dd $(6.4,4.3)$ \\
\hline 6 & $86.5, \mathrm{C}$ & & $87.2, \mathrm{C}$ & \\
\hline 7 & 44.7, $\mathrm{CH}_{2}$ & $3.73, \mathrm{~s}$ & $42.1, \mathrm{CH}_{2}$ & $3.67, d(5.4)$ \\
\hline 8 & 205.0, C & & $195.4, \mathrm{C}$ & \\
\hline 9 & $30.5, \mathrm{CH}_{3}$ & $2.20, \mathrm{~s}$ & 128.3, CH & $6.20, d(15.5)$ \\
\hline \multirow[t]{2}{*}{10} & $20.5, \mathrm{CH}_{2}$ & $1.25, \mathrm{dd}(14.1,7.2)$ & 143.9, $\mathrm{CH}$ & 7.24, dd $(15.5,10.9)$ \\
\hline & & 2.03, dd $(14.1,7.2)$ & & \\
\hline 11 & 8.6, $\mathrm{CH}_{3}$ & $0.82, \mathrm{t}(7.2)$ & 127.5, $\mathrm{CH}$ & $6.46, \mathrm{~m}$ \\
\hline \multirow[t]{2}{*}{12} & $35.0, \mathrm{CH}_{2}$ & $2.54, \mathrm{dd}(18.1,6.2)$ & 143.6, $\mathrm{CH}$ & $6.35, \mathrm{dt}(15.5,4.6)$ \\
\hline & & $2.99, \mathrm{dd}(18.1,6.2)$ & & \\
\hline 13 & 197.2 & & 62.6. $\mathrm{CH}_{2}$ & 4.34, d (4.6) \\
\hline \multirow[t]{2}{*}{14} & 127.6, $\mathrm{CH}$ & $6.14, d(15.5)$ & $35.1, \mathrm{CH}_{2}$ & 3.23, dd $(18.4,6.4)$ \\
\hline & & & & $2.46, \mathrm{dd}(18.4,4.3)$ \\
\hline 15 & $143.9, \mathrm{CH}$ & $7.17, \mathrm{dd}(15.5,10.1)$ & 196.6, C & \\
\hline 16 & 130.6, $\mathrm{CH}$ & $6.27, \mathrm{~m}$ & 126.8, $\mathrm{CH}$ & $6.11, d(15.5)$ \\
\hline 17 & $141.9, \mathrm{CH}$ & $6.32, \mathrm{~m}$ & 144.2, $\mathrm{CH}$ & 7.20, dd $(15.5,10.7)$ \\
\hline 18 & $19.1, \mathrm{CH}_{3}$ & 1.83, d (6.1) & 130.2, CH & $6.20, \mathrm{~m}$ \\
\hline 19 & $11.9, \mathrm{CH}_{3}$ & $1.70, \mathrm{~s}$ & 141.7, $\mathrm{CH}$ & $6.28, \mathrm{~m}$ \\
\hline 20 & $16.5, \mathrm{CH}_{3}$ & $1.37, \mathrm{~s}$ & $18.9, \mathrm{CH}_{3}$ & 1.88, d (6.6) \\
\hline 21 & $174.7, \mathrm{C}$ & & 11.6, $\mathrm{CH}_{3}$ & $1.78, \mathrm{~s}$ \\
\hline 22 & & & $16.1, \mathrm{CH}_{3}$ & $1.23, \mathrm{~s}$ \\
\hline 23 & & & $16.2, \mathrm{CH}_{3}$ & $1.46, \mathrm{~s}$ \\
\hline 24 & & & 176.1, C & \\
\hline
\end{tabular}

that two rings should be present in 1. A substituted 2,6,8,10tetra-methyl-8-hydroxy naphthalene 1,4,7-trione skeleton was deduced based on its spectroscopic features, combining with the key HMBC correlations from $\mathrm{H}-3$ to $\mathrm{C}-1$ and $\mathrm{C}-5$, from $\mathrm{H}_{3}-18$ to $\mathrm{C}-1, \mathrm{C}-2$, and $\mathrm{C}-3$, from $\mathrm{H}_{3}-19$ to $\mathrm{C}-4, \mathrm{C}-5, \mathrm{C}-6$, and $\mathrm{C}-7$, from $\mathrm{H}_{3}-20$ to $\mathrm{C}-7, \mathrm{C}-8$, and $\mathrm{C}-9$, and from $\mathrm{H}_{3}-21$ to C-1, C-5, C-9, and C-10 (Figure 2). A typical sorbyl side chain was deduced from the ${ }^{1} \mathrm{H}_{-}{ }^{1} \mathrm{H}$ COSY correlations $\mathrm{H}-13 / \mathrm{H}$ $14 / \mathrm{H}-15 / \mathrm{H}-16 / \mathrm{H}_{3}-17$ and $\mathrm{HMBC}$ correlation from $\mathrm{H}-14$ to $\mathrm{C}-12$ (Figure 2). Further, the ${ }^{1} \mathrm{H}-{ }^{1} \mathrm{H}$ COSY signal $\mathrm{H}-9 / \mathrm{H}_{2}-11$ and the HMBC correlations from $\mathrm{H}_{2}-11$ to $\mathrm{C}-8, \mathrm{C}-9, \mathrm{C}-10$, and $\mathrm{C}-12$ (Figure 2) demonstrated that the sorbyl side chain was connected to $\mathrm{C}-9$ bridged by $\mathrm{CH}_{2}-11$.

The relative configuration of $\mathbf{1}$ was determined by coupling constants and NOESY spectrum (Figure 3 ). The E-configurations of double bonds in the sorbyl side chain were deduced on the basis of the large coupling constant $\left(J_{\mathrm{H}-13 / \mathrm{H}-14}=15.5 \mathrm{~Hz}\right)$ and the NOESY correlation between $\mathrm{H}-14$ and $\mathrm{H}-16$. The NOESY correlation between $\mathrm{H}_{3}-20$ and $\mathrm{H}_{3}-21$ indicated the same orientation of these two methyls, whereas the protons $\mathrm{H}_{3}-20$ and $\mathrm{H}_{3}-21$ were simultaneously correlated with $\mathrm{H}_{2}-11$, reflecting that proton $\mathrm{H}-9$ should locate at the other orientation. Therefore, the relative configuration of $\mathbf{1}$ was assumed as $8 R^{*}, 9 S^{*}, 10 S^{*}$. The 
TABLE $3 \mid{ }^{1} \mathrm{H}$ and ${ }^{13} \mathrm{C}$ NMR spectroscopic data for compounds 5 and 7 .

\begin{tabular}{|c|c|c|c|c|}
\hline \multirow[t]{2}{*}{ No. } & \multicolumn{2}{|c|}{$5^{\mathrm{a}}$ in $\mathrm{CD}_{3} \mathrm{OD}$} & \multicolumn{2}{|c|}{$7^{\mathrm{b}}$ in $\mathrm{CD}_{3} \mathrm{OD}$} \\
\hline & $\delta_{c}$, type & $\delta_{\mathrm{H}},(J$ in $\mathrm{Hz})$ & $\delta_{c}$, type & $\delta_{\mathrm{H}},(\boldsymbol{J}$ in $\mathrm{Hz})$ \\
\hline 1 & $58.7, \mathrm{CH}$ & $3.08, \mathrm{~s}$ & 195.3, C & \\
\hline 2 & $104.6^{C}, C$ & & 106.5, C & \\
\hline \multirow[t]{2}{*}{3} & 201.3, C & & $36.5, \mathrm{CH}_{2}$ & $2.46, d(14.5)$ \\
\hline & & & & $2.74, d(14.5)$ \\
\hline 4 & $61.0^{d}, C$ & & 74.3, C & \\
\hline $4 a$ & & & 107.3, C & \\
\hline 5 & 105.8, C & & & \\
\hline $5 a$ & & & $80.6, \mathrm{C}$ & \\
\hline 6 & $80.4, \mathrm{C}$ & & 169.1, C & \\
\hline 7 & $58.7, \mathrm{CH}$ & $3.09, \mathrm{~s}$ & 110.7, C & \\
\hline 8 & $105.0^{\mathrm{C}}, \mathrm{C}$ & & 193.5, C & \\
\hline 9 & 201.9, C & & 102.6, C & \\
\hline $9 a$ & & & $55.1, \mathrm{CH}$ & $3.65, s$ \\
\hline $9 b$ & & & 60.6, C & \\
\hline 10 & $61.1^{d}, C$ & & 178.7, C & \\
\hline 11 & $105.8, \mathrm{C}$ & & 123.6, $\mathrm{CH}$ & $6.42, d(14.7)$ \\
\hline 12 & $80.4, \mathrm{C}$ & & 142.3, CH & $7.27, \mathrm{dd}(14.7,11.2)$ \\
\hline 13 & 175.9, C & & $129.7, \mathrm{CH}$ & $6.54, \mathrm{~m}$ \\
\hline 14 & 120.2, CH & $6.31, d(14.7)$ & 143.2, CH & $6.26, \mathrm{dd}(14.7,4.3)$ \\
\hline 15 & $144.2, \mathrm{CH}$ & $7.28, \mathrm{dd}(14.7,11.1)$ & $62.9, \mathrm{CH}_{2}$ & $4.22, \mathrm{~d}(4.3)$ \\
\hline 16 & $132.3, \mathrm{CH}$ & 6.37, m & $22.8, \mathrm{CH}_{3}$ & $1.21, \mathrm{~s}$ \\
\hline 17 & $140.8, \mathrm{CH}$ & $6.21, \mathrm{dd}(14.7,6.6)$ & $25.8, \mathrm{CH}_{3}$ & $1.43, \mathrm{~s}$ \\
\hline 18 & $18.9, \mathrm{CH}_{3}$ & $1.89, d(6.6)$ & $7.1, \mathrm{CH}_{3}$ & $1.41, \mathrm{~s}$ \\
\hline 19 & 175.2, C & & 168.6, C & \\
\hline 20 & 122.1, CH & $6.43, d(14.7)$ & $121.8, \mathrm{CH}$ & $6.49, d(14.7)$ \\
\hline 21 & $143.1, \mathrm{CH}$ & 7.33, dd $(14.7,11.3)$ & $139.4, \mathrm{CH}$ & $7.19, \mathrm{dd}(14.7,11.2)$ \\
\hline 22 & 129.7, CH & $6.56, \mathrm{dd}(14.7,11.3)$ & $132.5, \mathrm{CH}$ & $6.35, \mathrm{~m}$ \\
\hline 23 & $143.4, \mathrm{CH}$ & $6.27, \mathrm{dt}(14.7,4.4)$ & 137.3, $\mathrm{CH}$ & 6.11, dq $(14.7,6.6)$ \\
\hline 24 & $62.9, \mathrm{CH}_{2}$ & $4.22, d(4.4)$ & $18.7, \mathrm{CH}_{3}$ & $1.87, d(6.6)$ \\
\hline 25 & $19.8, \mathrm{CH}_{3}$ & $1.37, \mathrm{~s}$ & $20.1, \mathrm{CH}_{3}$ & $1.28, \mathrm{~s}$ \\
\hline 26 & $21.8, \mathrm{CH}_{3}$ & $1.35, \mathrm{~s}$ & & \\
\hline 27 & $19.8, \mathrm{CH}_{3}$ & $1.37, \mathrm{~s}$ & & \\
\hline 28 & $21.8, \mathrm{CH}_{3}$ & $1.35, \mathrm{~s}$ & & \\
\hline
\end{tabular}

${ }^{a}$ Recorded at $600 \mathrm{MHz}$ for ${ }^{1} \mathrm{H}$ NMR and at $150 \mathrm{MHz}$ for ${ }^{13} \mathrm{C} \mathrm{NMR}$. ${ }^{b}$ Recorded at $400 \mathrm{MHz}$ for ${ }^{1} \mathrm{H}$ NMR and at $100 \mathrm{MHz}$ for ${ }^{13} \mathrm{C} \mathrm{NMR} .{ }^{c, d}$ Assignment of signals might be exchanged.

absolute stereochemistry of $\mathbf{1}$ was resolved by quantum chemical time-dependent density functional theory (TDDFT) calculation of its electronic circular dichroism (ECD) spectra of $(8 R, 9 S, 10 S)$ $\mathbf{1}$ and $(8 S, 9 R 10 R)-\mathbf{1}$. The experimental ECD spectrum of $\mathbf{1}$ displayed the intense positive cotton effect at $252 \mathrm{~nm}$ and negative cotton effects at 227 and $288 \mathrm{~nm}$, respectively, which were consistent with the theoretical ECD spectrum for $(8 R, 9 S, 10 S)$ 1 (Figure 4). Therefore, the absolute configuration of 1 was determined as $8 R, 9 S, 10 S$.

Trichoreeseione B (2) was assigned a molecular formula of $\mathrm{C}_{21} \mathrm{H}_{24} \mathrm{O}_{6}$ by HR-ESIMS, showing one additional oxygen atom compared to that of $\mathbf{1}$. The NMR data of $\mathbf{2}$ (Table $\mathbf{1}$ ) suggested the same skeleton as $\mathbf{1}$, apart from a hydroxy-methylene resonance $\left(\delta_{\mathrm{H}} 4.31, \delta_{C}\right.$ 62.9) in 2 instead of the methyl signals $\left(\delta_{\mathrm{H}}\right.$ $\left.1.87, \delta_{C} 18.9\right)$ in 1 . The ${ }^{1} \mathrm{H}^{1}{ }^{1} \mathrm{H}$ COSY and $\mathrm{HMBC}$ correlations confirmed the planar structure of $\mathbf{2}$, in which a terminal hydroxymethylene in the sorbyl side chain replaced the methyl group in 1 (Figure 2). The coupling constants, NOESY correlations (Figure 3), and ECD spectrum of $\mathbf{2}$ (Figure 4) demonstrated that its stereochemistry was the same as $\mathbf{1}$. It is worth mentioning that compounds $\mathbf{1}$ and $\mathbf{2}$ represented the first example of sorbicillinoids with a characteristic naphthalene-trione ring.

Trichodermolide B (3) was given a molecular formula $\mathrm{C}_{21} \mathrm{H}_{26} \mathrm{O}_{5}$ based on HR-ESIMS, indicating 9 degrees of unsaturation. The ${ }^{1} \mathrm{H}$ NMR and ${ }^{13} \mathrm{C}$ NMR data (Table 2) showed four carbonyls, three pairs of olefinic carbons, five methyls, three methylenes, one methine, and two quaternary carbons. These spectroscopic features suggested that $\mathbf{3}$ should be a sorbicillinoid analog and closely resembled to trichodermolide isolated from Trichoderma longibrachiatum (strain UAMH 4159) collected from cotton duck shelter (Andrade et al., 1996). The main differences were absence of four olefinic carbons, and addition of a propan-2-one moiety and one methylene. The HMBC correlations from $\mathrm{H}_{2}-7$ to $\mathrm{C}-2, \mathrm{C}-3$ and C-4 suggested the propan-2-one moiety was attached to $\mathrm{C}-3$. The ${ }^{1} \mathrm{H}-{ }^{1} \mathrm{H}$ COSY linkage between $\mathrm{H}_{2}-10$ and $\mathrm{H}_{3}-11$ indicated the presence of one ethylene group, which was located at C-4 based on the HMBC correlations from $\mathrm{H}_{3}-11$ to $\mathrm{C}-4$, and from $\mathrm{H}_{2}-10$ to C-4, C-5, and C-21 (Figure 2).

The two double bonds in sorbyl side chain of 3 were also assigned as $E$ configuration on the basis of their coupling constants $\left(J_{\mathrm{H}-14 / \mathrm{H}-15}=15.5 \mathrm{~Hz}\right)$, and the NOESY correlation between $\mathrm{H}-14 / \mathrm{H}-16$ and $\mathrm{H}-15 / \mathrm{H}-17$ (Figure 3 ). The relative configurations of the stereocenters at C-4, C-5, and C-6 were determined by NOESY spectrum. The NOESY correlations of $\mathrm{H}-5 / \mathrm{H}_{3}-20$, and $\mathrm{H}-5 / \mathrm{H}_{3}-11$ suggested the same side of these protons. Therefore, the relative configuration of $\mathbf{3}$ was assumed as $4 S^{*}, 5 R^{*}, 6 R^{*}$. The absolute configuration of 3 was determined by ECD calculation. The Boltzmann-weighted ECD curve of $(4 S, 5 R, 6 R)-3$ agreed with the experimental one (Figure 4), and hence, the absolute configuration of $\mathbf{3}$ was assigned as $4 S, 5 R, 6 R$.

13-Hydroxy-trichodermolide (4) has a molecular formula $\mathrm{C}_{24} \mathrm{H}_{28} \mathrm{O}_{6}$ deduced by HR-ESIMS $m / z 413.1956[\mathrm{M}+\mathrm{H}]^{+}$ (calcd. for $\mathrm{C}_{24} \mathrm{H}_{29} \mathrm{O}_{6}, 413.1959$ ), indicating 11 degrees of unsaturation. The NMR data of 4 (Table 2) were very similar to those of trichodermolide isolated from $T$. longibrachiatum (strain UAMH 4159) (Andrade et al., 1996), except the terminal methyl group $\left(\delta_{\mathrm{H}} 1.88, \delta_{\mathrm{C}} 18.9\right)$ at $\mathrm{C}-13$ in trichodermolide was substituted by a hydroxy methylene group $\left(\delta_{\mathrm{H}} 4.34, \delta_{\mathrm{C}} 62.6\right)$ in 4 .

The $E$ configurations among the four double bonds in the side chains of $\mathbf{4}$ were confirmed by large coupling constant values $\left(J_{\mathrm{H}-9 / \mathrm{H}-10}=J_{\mathrm{H}-11 / \mathrm{H}-12}=J_{\mathrm{H}-16 / \mathrm{H}-17}=15.5 \mathrm{~Hz}\right)$ and the NOESY correlation between H-19/H-17 and H-16/H18 (Figure 3). The relative configurations of three stereocenters, C-4, C-5, and C- 6 of 4 were determined by comparison of its ${ }^{1} \mathrm{H}$ NMR data with already reported compound dihydrotrichodermolide ( $\mathrm{Li}$ et al., 2011). The similarity of chemical shifts of $\mathrm{H}-5\left(\delta_{\mathrm{H}} 3.33\right), \mathrm{H}_{2}-14\left(\delta_{\mathrm{H}} 3.23\right.$ and 2.46$)$, and two methyl groups $\mathrm{H}_{3}-22$ (1.23) and $\mathrm{H}_{3}-23\left(\delta_{\mathrm{H}} 1.46\right)$ in 4 with those of in dihydro-trichodermolide, combing the NOESY correlations between $\mathrm{H}-5 / \mathrm{H}_{3}-22$ and $\mathrm{H}-5 / \mathrm{H}_{3}-23$, established that the relative configuration of $\mathbf{4}$ was in accordance with that of 


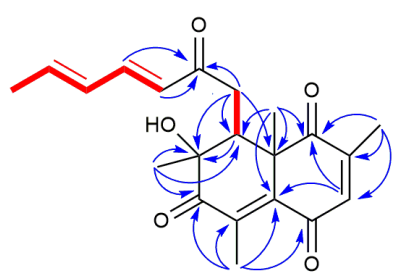

1

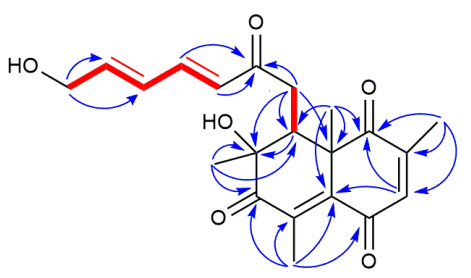

2

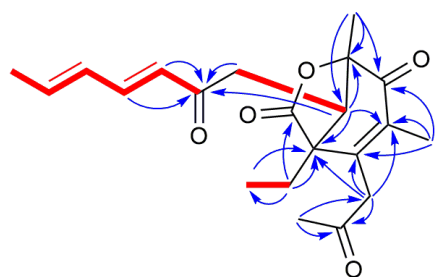

3

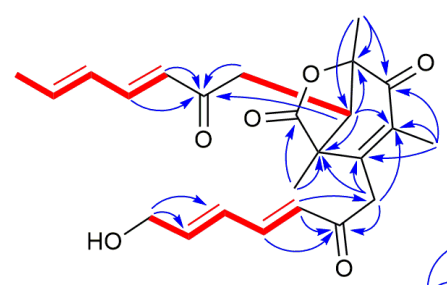

4

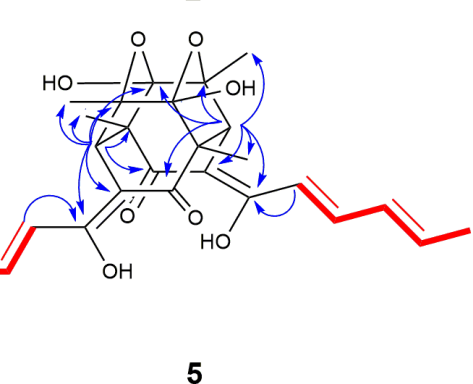

5

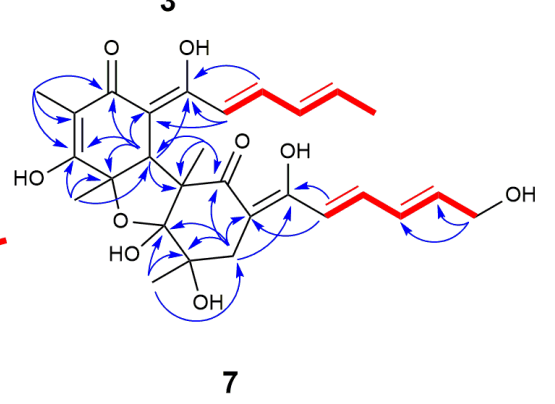

${ }^{1} \mathrm{H}^{-1} \mathrm{H} \operatorname{COSY} \longrightarrow \mathrm{HMBC}$

FIGURE $\mathbf{2} \mid \mathrm{Key}{ }^{1} \mathrm{H}-{ }^{1} \mathrm{H}$ COSY and $\mathrm{HMBC}$ correlations of $\mathbf{1 - 5}$ and $\mathbf{7}$.
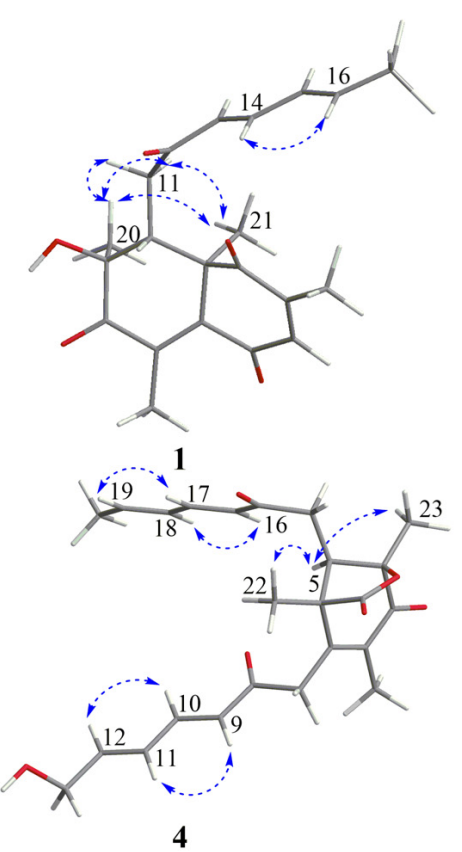

4

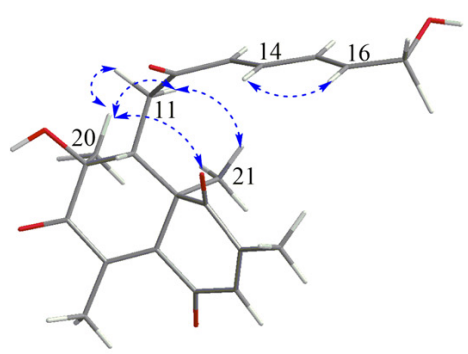

2

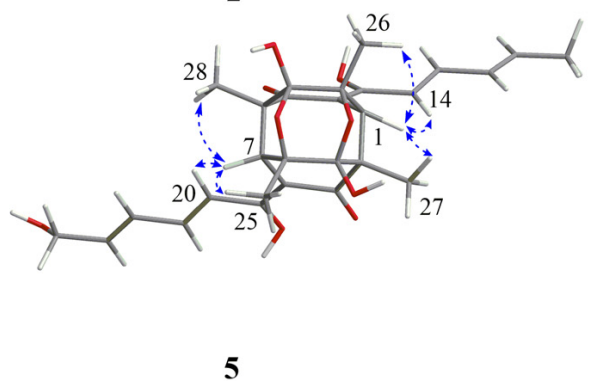

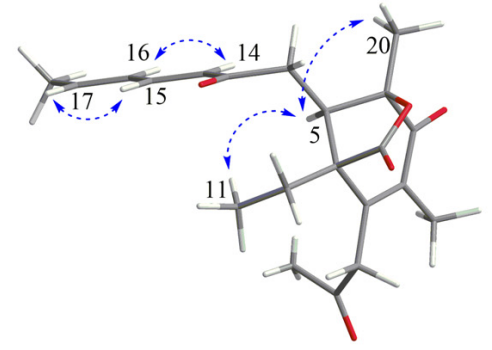

3

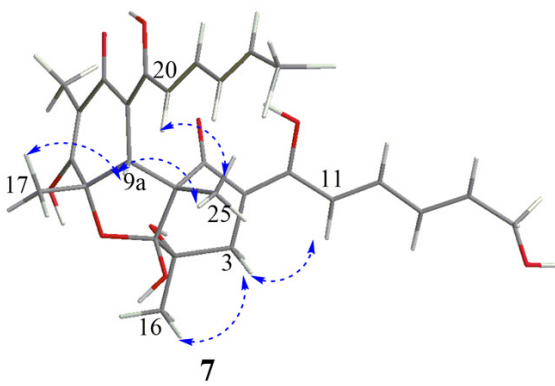

FIGURE $\mathbf{3}$ | Key NOESY correlations of 1-5 and $\mathbf{7}$.

dihydro-trichodermolide. The absolute configuration of $\mathbf{4}$ was determined by comparing its ECD data (Figure 4) with those of known analogs (Andrade et al., 1996; Li et al., 2011; Cao et al., 2019). The ECD spectrum of $\boldsymbol{4}$ demonstrated nearly similar negative and positive cotton effects to those of reported analogs (Figure 4 and Supplementary Table S4). Consequently, the absolute configuration of $\mathbf{4}$ was determined as $4 S, 5 R, 6 R$.
A literature survey revealed that bicycle (3.2.1) lactone skeleton was rare in the sorbicillinoid family. So far, only three compounds with this distinctive skeleton have been reported, including trichodermolide (Andrade et al., 1996), dihydro-trichodermolide (Li et al., 2011) and 13-hydroxydihydro-trichodermolide (Cao et al., 2019). In this study, two new sorbicillinoids (3 and 4 ) with a bicycle [3.2.1] lactone 

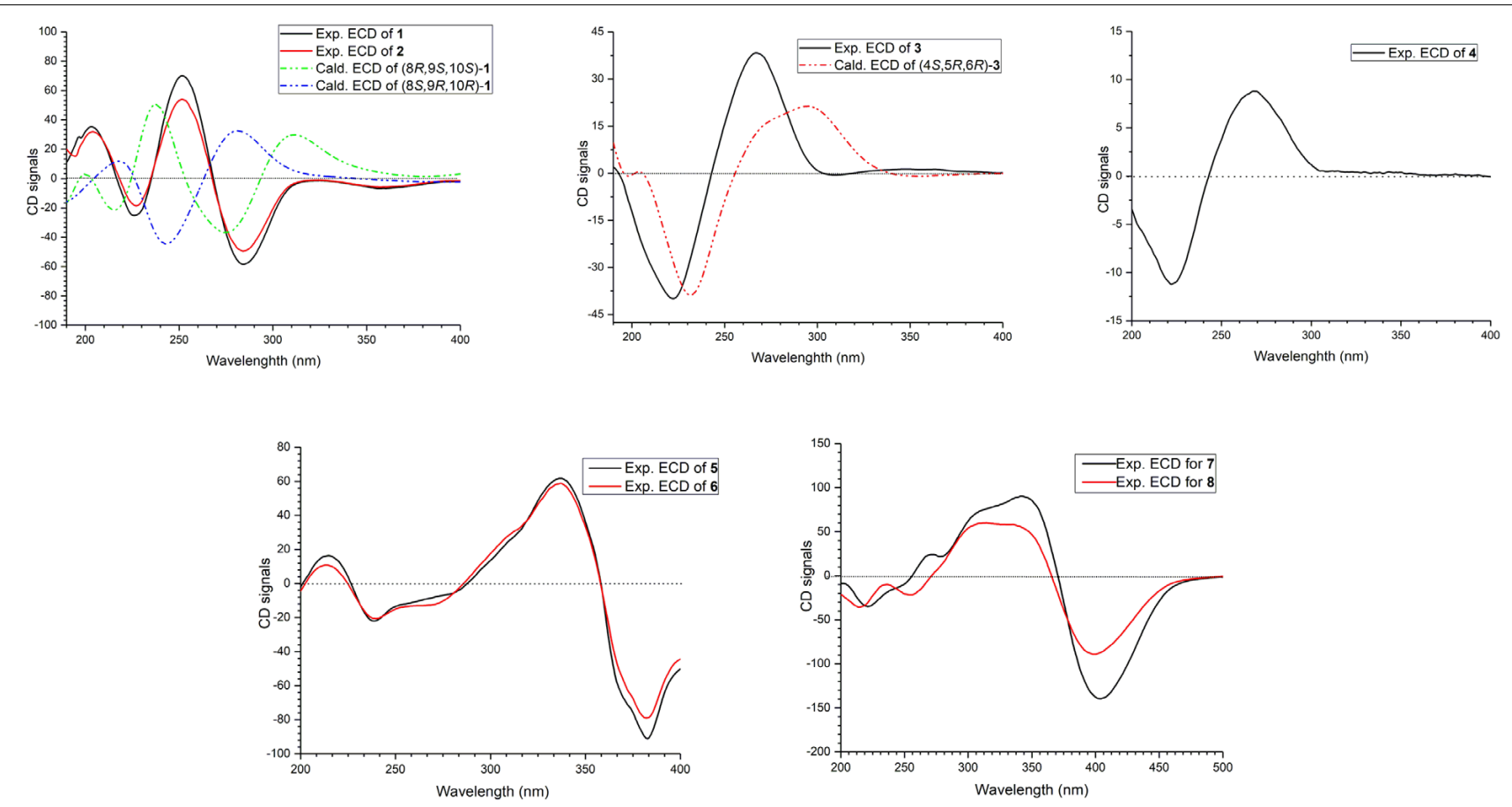

FIGURE $\mathbf{4}$ | ECD spectra of compounds $\mathbf{1 - 8}$

skeleton was discovered. Among them, 3 was unique in a sense that the propan-2-one side chain was reported first time for sorbicillinoid family.

24-Hydroxy-trichodimerol (5) was assigned the molecular formula $\mathrm{C}_{28} \mathrm{H}_{32} \mathrm{O}_{9}$ by HR-ESIMS with 13 degrees of unsaturation. The NMR spectra (Table 3) of 5 exhibited resembling resonances with those of the co-isolated known compound trichodimerol (6), which was firstly isolated from T. longibrachiatum (strain UAMH 4159) (Andrade et al., 1992). The only obvious difference was the terminal methyl group $\left(\delta_{\mathrm{H}}\right.$ $\left.1.89 \delta_{\mathrm{C}} 18.8\right)$ at C-24 of sorbyl residue in 6 was replaced by a hydroxylated methylene group $\left(\delta_{\mathrm{H}} 4.22, \delta_{\mathrm{C}} 62.9\right)$ in $\mathbf{5}$.

The stereochemistry of the double bonds in the sorbyl chains in 5 was assigned as $E$ configurations based on

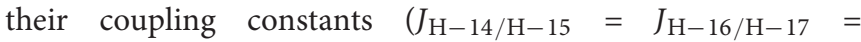
$\left.J_{\mathrm{H}-20 / \mathrm{H}-21}=J_{\mathrm{H}-22 / \mathrm{H}-23}=14.7 \mathrm{~Hz}\right)$. Moreover, in the NOESY spectrum, the correlations between $\mathrm{H}-1$ and $\mathrm{H}-14$, $\mathrm{H}_{3}-26, \mathrm{H}_{3}-27$, respectively, and between $\mathrm{H}-7$ and $\mathrm{H}-20$, $\mathrm{H}_{3}-25, \mathrm{H}_{3}-28$, respectively, were observed (Figure 3), suggesting the same relative configurations of $\mathbf{5}$ and $\mathbf{6}$. The absolute configuration of $\mathbf{5}$ was determined by comparing its ECD spectrum with $\mathbf{6}$. Compound 5 displayed strong positive Cotton effect at $338 \mathrm{~nm}(+62)$ and negative Cotton effect at $383 \mathrm{~nm}(-91)$, which was similar with that of 6 (Figure 4). Therefore, the absolute configuration of $\mathbf{5}$ was assumed as $1 R, 4 R, 5 R, 6 S, 7 R, 10 R, 11 R, 12 S$ (Figure 1). It is worth noting that bisorbicillinoids possessing open-ended cage skeleton were uncommon active compounds (Zhai et al., 2016), of which trichodimerol was biomimetic total synthesized by Nicolaou et al. (2000).
15-Hydroxy-bisvertinol (7) displayed a $[\mathrm{M}-\mathrm{H}]^{-}$ion at $m / z 513.2136$ in its HR-ESIMS, in accordance with the molecular formula $\mathrm{C}_{28} \mathrm{H}_{33} \mathrm{O}_{9}$, which indicated 12 degrees of unsaturation. The 1D NMR and HSQC spectra displayed the presence of five methyls, two methylenes, nine methines, and twelve quaternary carbons. Careful examination of the NMR data of 7 (Table 3) disclosed that its skeleton has resemblance with the known compound bisvertinol (9), primarily isolated from fungus Verticillium intertextum (Trifonov et al., 1986). The obvious difference was that the methyl group at C-15 on one of the sorbyl side chains in $\mathbf{9}$ was replaced by a hydroxy methylene in 7 .

The relative configuration of 7 was addressed by the coupling constants, NOESY spectrum and biogenetic relationship. The large coupling constants of the four double bonds in the sorbyl chains $\left(J_{\mathrm{H}-11 / \mathrm{H}-12}=J_{\mathrm{H}-13 / \mathrm{H}-14}=J_{\mathrm{H}-20 / \mathrm{H}-21}=J_{\mathrm{H}-22 / \mathrm{H}-23}\right.$ $=14.7 \mathrm{~Hz}$ ) reflected their E-configurations. In the NOESY spectrum, key cross peaks were observed between $\mathrm{H}-9 \mathrm{a}$ and $\mathrm{H}_{3}$ 25 and $\mathrm{H}_{3}-17$ (Figure 3), indicating that the methyls $\mathrm{H}_{3}-17$ and $\mathrm{H}_{3}-25$ were at the same side with $\mathrm{H}-9 \mathrm{a}$. The $4 \mathrm{a}-\mathrm{OH}$ was deduced in the same face with $\mathrm{H}-9 \mathrm{a}, \mathrm{H}_{3}-25$ and $\mathrm{H}_{3}-17$ by considering the higher stability of a cis 5-6 ring junction over a trans 56 ring junction (Andrade et al., 1992). The configuration of C-4 was presumed to be identical to that of the co-isolated 8 and 9 on the basis of biogenetic relationship. The experimental ECD spectra of 7 and 8 (Figure 4) were parallel to each other, possessing positive Cotton effect at $346 \mathrm{~nm}$ and negative at $403 \mathrm{~nm}$, and both gave negative optical rotation values. Consequently, the absolute configuration of 7 was deduced as $4 S, 4 \mathrm{a} R, 5 \mathrm{a} S, 9 \mathrm{a} R, 9 \mathrm{~b} R$. 
The structures of known compounds, trichodermol (6) (Andrade et al., 1992), 24-hydroxy-bisvertinol (8) (Zhang et al., 2019), and bisvertinol (9) (Trifonov et al., 1986), were recognized by comparing their spectroscopic data $\left({ }^{1} \mathrm{H}\right.$ and ${ }^{13} \mathrm{C} \mathrm{NMR}$, and MS) with those reported in the literature.

\section{Bioassays of Compounds}

All of the isolated new compounds (1-5 and 7) were assessed for their cytotoxic activities against five human tumor cell lines, including A549, HepG2, HCT 116, HeLa, MCF7 and two healthy human cell lines HUVEC and CLiver. Compound 5 displayed cytotoxic activity against A549, MCF7 and HCT 116 cell lines (Figure 5) with the $\mathrm{IC}_{50}$ values of 5.1, 9.5 and $13.7 \mu \mathrm{M}$, respectively, whereas displayed no significant cytotoxic activity against normal cell lines (HUVEC and CLiver) with the $\mathrm{IC}_{50}$ values higher than $40 \mu \mathrm{M}$. The selectivity index values (SI, $\mathrm{IC}_{50}$ normal cell line/ $\mathrm{IC}_{50}$ cancer cell line) for compound $\mathbf{5}$ were found
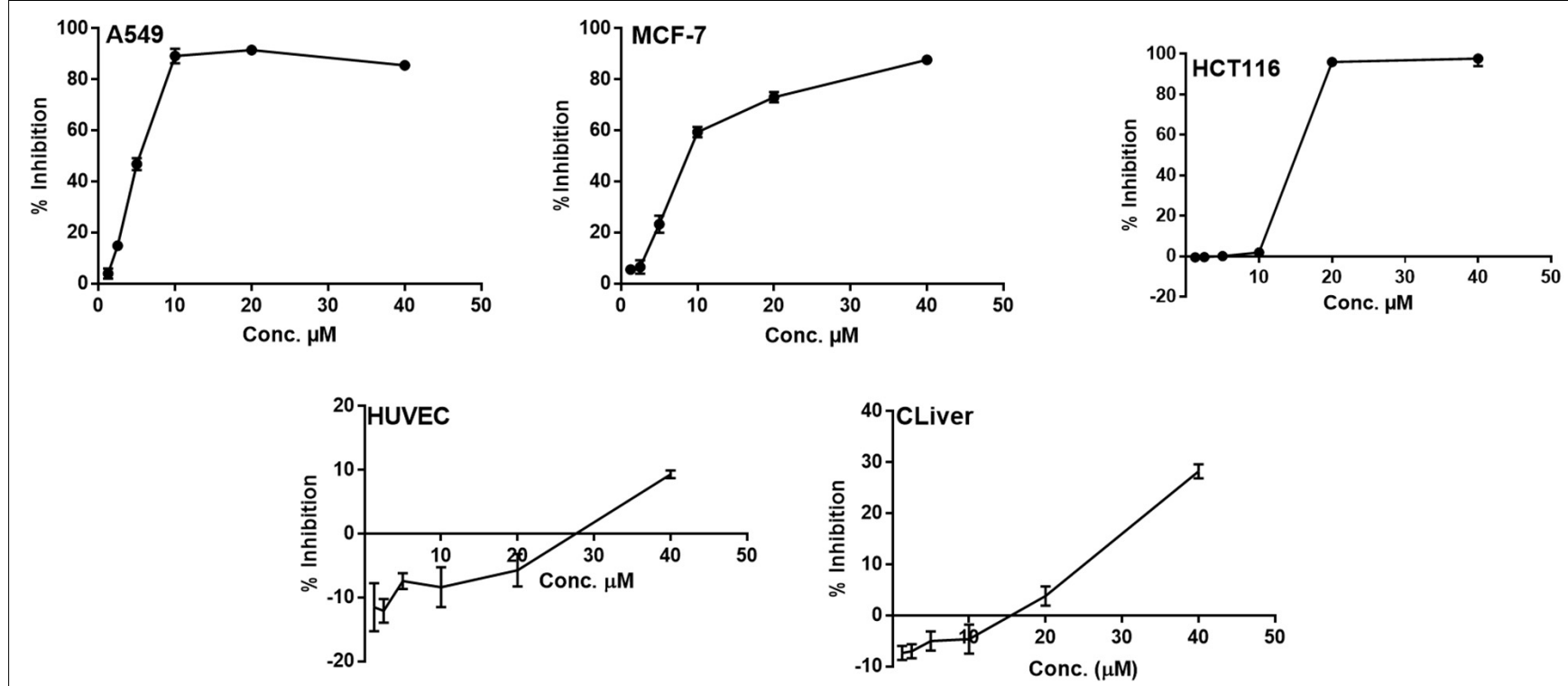

FIGURE $\mathbf{5}$ | The dose response curve of the cytotoxicity of compound $\mathbf{5}$ toward A549, MCF-7 HCT 116, HUVEC and CLiver cell lines. Cells were exposed to compound $\mathbf{5}$ with different concentrations for $72 \mathrm{~h}$. Cell inhibition was determined by SRB stain.
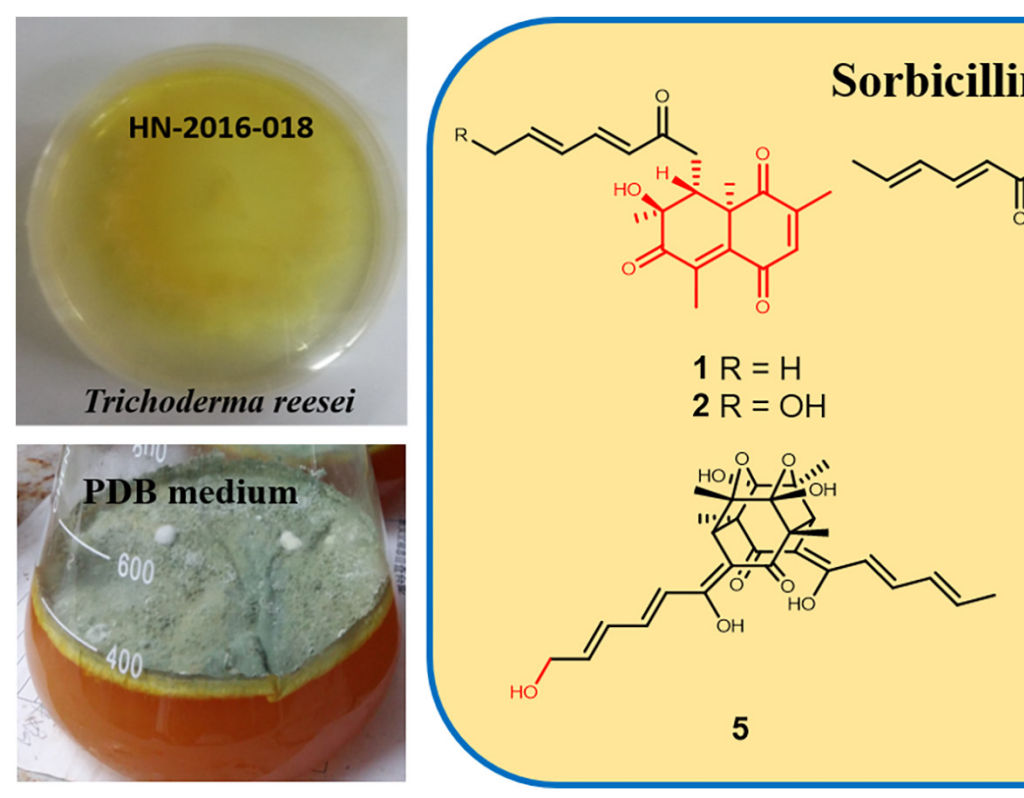

5

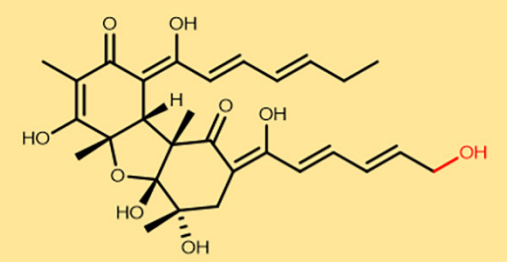

7

FIGURE 6 | Structural features of isolated sorbicillinoids. 
to be higher than $7.8,4.2$, and 2.9 , respectively, indicating its selective cytotoxicity.

\section{CONCLUSION}

In summary, we report here nine sorbicillinoid derivatives (19), including six new compounds, isolated from the spongederived fungus $T$. reesei $(\mathrm{HN}-2016-018)$. To date, more than 130 sorbicillinoid derivatives have been reported (Meng et al., 2016, 2018, 2019; Zhang et al., 2018, 2019; Cao et al., 2019; Wang et al., 2019; Yu et al., 2019). In this study, we discovered two novel sorbicillinoids (1-2) with a characteristic naphthalenetrione ring and two rare sorbicillinoids (3-4) possessing a bicycle (3.2.1) lactone skeleton (Figure 6), where only three compounds with such distinctive skeleton have been reported previously. Furthermore, compound 3 represented the first reported sorbicillinoid with a propan-2-one side chain, while a terminal hydroxylation at the side chain of compounds 2, 4, 5, and 7 was also rare in the sorbicillinoid family. Compound 5 displayed strong cytotoxic activity against A549, MCF-7, and HCT116 cell lines. This study enriched the structural diversity of sorbicillinoids and provided the chemical entities for the development of marine bioactive natural products.

\section{DATA AVAILABILITY STATEMENT}

The original contributions presented in the study are included in the article/Supplementary Material, and further inquiries can be directed to the corresponding author/s.

\section{REFERENCES}

Abe, N., Murata, T., and Hirota, A. (1998). Novel DPPH radical scavengers, bisorbicillinol and demethyltrichodimerol, from a fungus. Biosci. Biotech. Bioc. 62, 661-666. doi: 10.1271/bbb.62.661

Andrade, R., Ayer, W. A., and Mebe, P. P. (1992). The metabolites of Trichoderma longibrachiatum. Part 1. isolation of the metabolites and the structure of trichodimerol. Can. J. Chem. 70, 2526-2535. doi: 10.1139/v92-320

Andrade, R., Ayer, W. A., and Trifonov, L. S. (1996). The metabolites of Trichoderma longibrachiatum. Part II The structures of trichodermolide and sorbiquinol. Can. J. Chem. 74, 371-379. doi: 10.1139/v96-042

Bruhn, T., Schaumlöffel, A., Hemberger, Y., and Bringmann, G. (2013). SpecDis: quantifying the comparison of calculated and experimental electronic circular dichroism spectra. Chirality 25, 243-249. doi: 10.1002/chir.22138

Cao, M. J., Zhu, T., Liu, J. T., Ouyang, L., Yang, F., and Lin, H. W. (2019). New sorbicillinoid derivatives with GLP-1R and eEF2K affinities from a spongederived fungus Penicillium chrysogenum 581F1. Nat. Prod. Res. 33, 1-7. doi: 10.1080/14786419.2019.1596099

Du, L., Zhu, T. J., Li, L. Y., Cai, S. X., Zhao, B. Y., and Gu, Q. Q. (2009). Cytotoxic sorbicillinoids and bisorbicillinoids from a marine-derived fungus Trichoderma sp. Chem. Pharm. Bull. 57, 220-223. doi: 10.1248/cpb.57.220

Ei-Elimat, T., Raja, H. A., Figueroa, M., Swanson, S. M., Falkinham, J. O., Lucas, D. M., et al. (2015). Sorbicillinoid analogs with cytotoxic and selective antiAspergillus activities from Scytalidium album. J. Antibiot. 68, 191-196. doi: 10.1038/ja.2014.125

Felsenstein, J. (1985). Confidence limits on phylogenies: an approach using the bootstrap. Evolution 39, 783-791. doi: 10.1111/j.1558-5646.1985.tb00420.x

\section{AUTHOR CONTRIBUTIONS}

C-YW and C-LS conceived of and proposed the idea. SR contributed to fermentation, extraction, and isolation. SR and L-JY contributed to the manuscript preparation. WH contributed to bioactivities test. SR, L-JY, J-SW, TS, and Y-HZ contributed to data analysis, write up, revision, and proofreading of the manuscript. All authors read and approved the final manuscript.

\section{FUNDING}

This work was supported by the Marine S\&T Fund of Shandong Province for Pilot National Laboratory for Marine Science and Technology (Qingdao, China) (2018SDKJ0406-5), the National Natural Science Foundation of China (Nos. 41830535 and U1706210), and the National Science and Technology Major Project for Significant New Drugs Development, China (No. 2018ZX09735-004). We appreciated the Program of Open Studio for Druggability Research of Marine Natural Products, Pilot National Laboratory for Marine Science and Technology (Qingdao, China) directed by Kai-Xian Chen and Yue-Wei Guo, and the Taishan Scholars Program, China.

\section{SUPPLEMENTARY MATERIAL}

The Supplementary Material for this article can be found online at: https://www.frontiersin.org/articles/10.3389/fmicb. 2020.01334/full\#supplementary-material

Harned, A. M., and Volp, K. A. (2011). The sorbicillinoid family of natural products: isolation, biosynthesis, and synthetic studies. Nat. Prod. Rep. 28, 1790-1810.

Li, D., Xu, Y., Shao, C. L., Yang, R. Y., Zheng, C. J., Chen, Y. Y., et al. (2012). Antibacterial bisabolane-type sesquiterpenoids from the sponge-derived fungus Aspergillus sp. Mar. Drugs 10, 234-241. doi: 10.3390/md10010234

Li, D. H., Cai, S. X., Zhu, T. J., Wang, F. P., Xiao, X., and Gu, Q. Q. (2011). New cytotoxic metabolites from a deep-sea-derived fungus. Phialocephala sp., Strain FL30r. Chem. Biodivers. 8, 895-901. doi: 10.1002/cbdv.201000134

Liu, L., Zheng, Y. Y., Shao, C. L., and Wang, C. Y. (2019). Metabolites from marine invertebrates and their symbiotic microorganisms: molecular diversity discovery, mining, and application. Mar. Life Sci. Tech. 1, 60-94. doi: 10.1007/ s42995-019-00021-2

Meng, J. J., Cheng, W., Heydari, H., Wang, B., Zhu, K., Konuklugil, B., et al. (2018) Sorbicillinoid-based metabolites from a sponge-derived fungus Trichoderma saturnisporum. Mar. Drugs 16:226. doi: 10.3390/md16070226

Meng, J. J., Gu, G., Dang, P. Q., Zhang, X. P., Wang, W. X., Dai, J. G., et al. (2019). Sorbicillinoids from the fungus Ustilaginoidea virens and their phytotoxic, cytotoxic, and antimicrobial activities. Front. Chem. 7:435. doi: 10.3389/fchem. 2019.00435

Meng, J. J., Wang, X. H., Xu, D., Fu, X. X., Zhang, X. P., Lai, D. W., et al. (2016). Sorbicillinoids from fungi and their bioactivities. Molecules 21:715. doi: 10.3390/molecules21060715

Nicolaou, K. C., Vassilikogiannakis, G., Simonsen, K. B., Baran, P. S., Zhong, Y. L., Vidali, V. P., et al. (2000). Biomimetic total synthesis of bisorbicillinol, bisorbibutenolide, trichodimerol, and designed analogues of the bisorbicillinoids. J. Am. Chem. Soc. 122, 3071-3079. doi: 10.1021/ja9942843 
Peng, J., Zhang, X., Du, L., Wang, W., Zhu, T., Gu, Q., et al. (2014). Sorbicatechols $\mathrm{A}$ and $\mathrm{B}$, antiviral sorbicillinoids from the marine-derived fungus Penicillium chrysogenum PJX-17. J. Nat. Prod. 77, 424-428. doi: 10.1021/np400977e

Qi, J., Shao, C. L., Li, Z. Y., Gan, L. S., Fu, X. M., Bian, W. T., et al. (2013). Isocoumarin derivatives and benzofurans from a sponge-derived Penicillium sp. fungus. J. Nat. Prod. 76, 571-579. doi: 10.1021/np3007556

Saitou, N., and Nei, M. (1987). The neighbor-joining method: a new method for reconstructing phylogenetic trees. Mol. Biol. Evol. 4, 406-425.

Skehan, P., Storeng, R., Scudiero, D., Monks, A., McMahon, J., Vistica, D., et al. (1990). New colorimetric cytotoxicity assay for anticancer-drug screening. J. Natl. Cancer I. 82, 1107-1112. doi: 10.1093/jnci/82.13.1107

Trifonov, L. S., Hilpert, H., Floersheim, P., Dreiding, A. S., Rast, D. M., Skrivanova, R., et al. (1986). Bisvertinols: a new group of dimeric vertinoids from Verticillium intertextum. Tetrahedron 42, 3157-3179. doi: 10.1016/s00404020(01)87382-8

Wang, C. Y., Hao, J. D., Ning, X. Y., Wu, J. S., Zhao, D. L., Kong, C. J., et al. (2018). Penicilazaphilones D and E: two new azaphilones from a sponge-derived strain of the fungus Penicillium sclerotiorum. RSC Adv. 8, 3438-3453.

Wang, J. J., Li, K. L., Luo, X. W., Wu, Z. Y., Gu, T. W., Liao, S. R., et al. (2019). Sorbicillfurans A and B, two novel sorbicillinoid adducts from the fungus Penicillium citrinum SCSIO41402. Org. Biomol. Chem. 17, 8721-8725. doi: 10.1039/c9ob01595g

Wu, J. S., Yao, G. S., Shi, X. H., Rehman, S. U., Xu, Y., Fu, X. M., et al. (2020). Epigenetic agents trigger the production of bioactive nucleoside derivatives and bisabolane sesquiterpenes from the marine-derived fungus Aspergillus versicolor. Front. Microbiol. 11:85. doi: 10.3389/fmicb.2020.00085

Yu, J., Han, H., Zhang, X. Y., Ma, C. T., Sun, C. X., Che, Q., et al. (2019). Discovery of Two new sorbicillinoids by overexpression of the global regulator LaeA in a marine-derived fungus Penicillium dipodomyis YJ-11. Mar. Drugs 17:446. doi: 10.3390/md17080446

Zhai, M. M., Qi, F. M., Li, J., Jiang, C. X., Hou, Y., Shi, Y. P., et al. (2016). Isolation of secondary metabolites from the soil-derived fungus Clonostachys rosea YRS06, a biological control agent, and evaluation of antibacterial activity. J. Agric. Food Chem. 64, 2298-2306. doi: 10.1021/acs.jafc.6b00556

Zhang, P. P., Deng, Y. L., Lin, X. J., Chen, B., Li, J., Liu, H. J., et al. (2019). Anti-inflammatory mono-and dimeric sorbicillinoids from the marine-derived fungus Trichoderma reesei 4670. J. Nat. Prod. 82, 947-957. doi: 10.1021/acs. jnatprod.8b01029

Zhang, Z. Z., He, X. Q., Che, Q., Zhang, G. J., Zhu, T. J., Gu, Q. Q., et al. (2018). Sorbicillasins A-B and scirpyrone K from a deep-sea-derived fungus, Phialocephala sp. FL30r. Mar. Drugs 16:245. doi: 10.3390/md16070245

Zhao, D. L., Shao, C. L., Gan, L. G., Wang, M., and Wang, C. Y. (2015). Chromone derivatives from a sponge-derived strain of the fungus Corynespora cassiicola. J. Nat. Prod. 78, 286-293. doi: 10.1021/np5009152

Conflict of Interest: The authors declare that the research was conducted in the absence of any commercial or financial relationships that could be construed as a potential conflict of interest.

Copyright (C) 2020 Rehman, Yang, Zhang, Wu, Shi, Haider, Shao and Wang. This is an open-access article distributed under the terms of the Creative Commons Attribution License (CC BY). The use, distribution or reproduction in other forums is permitted, provided the original author(s) and the copyright owner(s) are credited and that the original publication in this journal is cited, in accordance with accepted academic practice. No use, distribution or reproduction is permitted which does not comply with these terms. 